\title{
Improving Student Communication Skills in Learning Indonesian Language through Collaborative Learning
}

\author{
Reni Kusmiarti, Ira Yuniati, Noermanzah
}

\begin{abstract}
Some research results state that students' communication skills have not shown adequate abilities. In terms of communication skills can affect the development of intellectual abilities, emotional and social maturity, and solving various problems faced by them at school. This research is intended to provide an understanding of improving students' communication skills in learning Indonesian through Collaborative Learning at SMK Negeri 1 Bengkulu City. This type of research is a classroom action research with Hopkins model. Data collection techniques carried out in the form of observation, tests, and documentation. Data analysis techniques through the analysis of observational data, calculating the average value of communication skills, analyzing documentation data, and conclusions. The data validity test uses a data source triangulation test. Based on the results of the study note that there is an increase in communication skills, both verbal skills, vocal skills, and body skills of high school students.
\end{abstract}

Index Terms - communication skills, collaborative learning, Indonesian language learning.

\section{INTRODUCTION}

Education is the sector that is considered most responsible for preparing young people for their future. The National Education Standards Agency (BNSP) publishes elements in the global learning framework in the curriculum in Indonesia called 4C, namely: 1) critical thinking and problem solving skills, 2) communication skills, 3) creativity and innovation and 4) collaboration. The practice of education and learning in Indonesia in the future will prioritize the ability to critical thinking, creative, collaboratively, and develop communication skills (Karto et al. 2019: 2718).

According to (Nofrion, 2018), communication skills are one of the keys to success in living and surviving in the Era of Industrial Revolution 4.0 and Era of Disruption. Nofrion further said that communication skills as a soft skill occupy the top position of all types of skills needed by the business world and the world of work and contribute $82 \%$ to one's success. Communicating in learning is communicating ideas and ideas, opinions, giving questions, giving answers, and responses. Communication energy is intended to achieve learning objectives. One factor for the learning process to run well is the students' communication skills. Through good communication skills, students are expected to be able to respond to various knowledge received, understand, and solve problems received at school.

Language skills are a very important and fundamental ability to interact and express ideas to others so that they are easy to understand and communication between people will take place well. Communication can be in the form of expressions of thoughts, ideas, ideas, opinions, agreements, desires, delivery of information about an event, and others. Improving the communication skills of a student is needed to improve

- Reni Kusmiarti, Universitas Muhammadiyah Bengkulu, Bengkulu City, Indonesia, E-mail: renikusmiarti@umb.ac.id

- Ira Yuniati, Universitas Muhammadiyah Bengkulu, Bengkulu City, Indonesia, E-mail: irayuniati@umb.ac.id

- Noermanzah, Bengkulu University, Bengkulu City, Indonesia, E-mail: noermanzah@unib.ac.id intellectual abilities, emotional maturity, and social maturity. According to Nelson \& Jones (2012), there are three aspects of communication skills, namely verbal skills, including formal language, informal language, and material content. Vocal skills are related to sound, including articulation, intonation (high low), tempo (speed of speech), accentuation (emphasis), and volume. Body skills consist of messages sent through bodily movements as expressions that are being expressed include, facial expressions, eye contact, gestures, and appearance. According to Hardjana (2003), there are two communications namely verbal and nonverbal communication. Verbal communication is communication that uses words that are verbal language both oral, written, and electronic, while in nonverbal communication the language used is nonverbal language in the form of body language (facial expressions, head movements, hand movements), signs, actions, and objects. This is supported by the opinion of Maulana \& Gumelar (2013), which says that verbal messages are realized through language/linguistics related to words and meanings, as well as language and thinking and nonverbal messages illustrated through body cues including all expressions that are realized or not realized in the form of gestures, gestures, facial expressions, tone or vibration of sound, and breathing. Chaer \& Agustina (2004), also said that language as a communication tool consists of two aspects, namely linguistic aspects and paralinguistic aspects. Linguistic aspects include phonology, morphology, and syntax. The paralinguistic aspects include speech quality, suprasegmental elements such as pressure, tone and intonation; distance and body movements, palpation regarding the sense of taste (skin). The linguistic and linguistic aspects function as a communication tool together with the context of the situation building certain situations in the communication process.

Research about communication has been done a lot. A study by Wicaksono (2013) showed the result that the role-playing technique in group guidance can improve interpersonal communication skills of class $X$ Multimedia SMK IKIP 
Surabaya students. Furthermore, according to Zuhara (2015), the sociodrama technique is significantly related to increasing the interpersonal communication skills of class $X$ students of SMA Kartika Siliwangi 2 Bandung. Research by Dharmayanti (2013) also states that role-playing techniques can improve interpersonal communication skills of SMK students in the Hospitality Accommodation Department.

Based on some of the research above, language skills can be improved with the role-playing techniques, sociodrama techniques, role-playing techniques in students, but communication skills with collaborative learning are still not widely practiced. Collaborative learning focuses on the collaborative process and focuses on the collaboration product. Collaborative learning is a learning strategy with a number of students as members of a learning group who work together actively to achieve the goals specified in an activity with a certain structure so that a meaningful learning process occurs (Widodo, 2013). According to Suryani (2009), some principles that need to be considered in collaborative learning are that each member works together to achieve shared goals and interdependence, individuals are responsible for the basis of their learning and behavior, cooperative skills are taught, practiced and feedback (feedback) is given based on how the skills training should be applied and the class or group being pushed towards the implementation of a cohesive group work activity. From these work principles, five basic elements are obtained so that cooperative learning/collaborative learning takes place, namely positive interdependence, direct interaction between students, individual accountability, collaborative skills, and the effectiveness of group processes. This is supported by the opinion of Hill \& Tim (1996) who say that collaborative classes can increase sensitivity and concern for one another so that positive cooperation can be developed and can develop the ability to communicate ideas.

Based on observations of students at the Vocational School during the learning process, it appears that students are less able to communicate well in the learning process, students look less confident / nervous when talking in class. This is justified by the teacher who teaches that the students at this vocational school, quite a lot are less able to communicate.

So far the communication skills of vocational students have not shown adequate communication skills. Language use skills have not been satisfactory at 58\%, both verbal skills, vocal skills, and body skills. Teachers teach only by lecture and discussion methods. The learning process with discussion is mostly played by the teacher as the subject of the subject. Preliminary observations in one of the vocational classes showed that there were still many students who were hesitant to speak. There is a fear of speaking. The atmosphere of learning becomes passive and not enthusiastic, due to the lack of courage to speak up to express opinions or ask questions. When it comes to articulation, intonation is still lacking, the tempo of the speech is still slow, accentuation (emphasis), and the volume is still not stable. Facial expressions indicate anxiety, eye contact is not so brave looking at the faces of friends and teachers, gestures, and appearances show doubts. The researcher intends to improve the classroom atmosphere to be more active and enthusiastic, dare to express opinions in front of the class. This situation encourages researchers to research overcoming teacher difficulties in teaching students to have good communication skills with collaborative learning. Learning with Collaborative Learning can create learning environments that are student-centered, contextual, integrated, and have a cooperative atmosphere and provide opportunities for students to become active participants in the learning process. The problem that will be examined in this study is Can collaborative learning improve communication skills of SMK Negeri 1 Bengkulu students? To provide an understanding of improving communication skills of SMK Negeri 1 Bengkulu students in Indonesian Language Learning with the Collaborative Learning method.

\section{RESEARCH METHODS}

The research method used is the Classroom Action Research method with the Hopkins model. PTK was implemented to improve communication skills through collaborative learning of SMK Negeri 1 Bengkulu City students. This study involved 35 students of SMK Negeri 1 Bengkulu class 2 as research subjects.

The implementation of Indonesian language learning through collaborative learning to improve communication skills of SMK Negeri 1 Bengkulu students is carried out in two stages. Each stage is carried out with different materials. The difference in learning material, the condition of students and lecturers of the model will certainly affect the communication skills of students. This research procedure consists of two cycles of research activities, which in general each cycle includes several stages, namely: the planning stage, the stage of implementing the action, observation, and reflection.

In Cycle 1, the Basic Competencies to be achieved in learning are describing (problems, arguments, knowledge, and recommendations) exposition texts related to the field of work being heard and read. Furthermore, the Basic Competency to be achieved in Cycle 2 is to develop content (problems, arguments, knowledge, and recommendations) of exposition text related to the field of work both orally and in writing. The performance indicator of this research is $70 \%$ of students already have the ability to communicate, both verbal skills, vocal skills, and body skills.

Data collection techniques using observation techniques, tests, and documentation. The observation technique used the student activity observation sheet instrument and the teacher activity observation sheet in the learning process. Teacher observation sheet to find out how the implementation of collaborative learning in improving student communication skills. Student observation sheets to find out how student activity learns by collaborative learning and how students' communication skills. Then, the data analysis technique is through analyzing observational data, calculating the average value of communication skills, analyzing documentation data, and conclusions. Data validity test uses a triangulation test of data sources obtained from observations, tests, and documentation. 


\section{RESULTS AND DISCUSSION}

\subsection{Results}

\subsubsection{Cycle 1}

The results of teacher observation in cycle 1 show that the model teacher has not fully implemented learning in accordance with the Learning Implementation Plan. At the preliminary stage the teacher has not implemented apperception aimed at linking prior knowledge with the knowledge to be learned. Besides the implementation at the core stage, the model teacher has not been able to provoke, facilitating students to participate in responding, asking questions in learning. The teacher is not focused and is not paying enough attention to the achievement of students 'communication skills, and has not been able to motivate students to be able to express their thoughts by asking questions, responding to peers' questions. The teacher has not integrated with the students, so it looks rigid in teaching.

Furthermore, the results of observations of students in cycle 1 show that students still look unfamiliar with the model teacher, the behavior of students who have not expressed serious interest, they appear rigid, nervous, afraid and have not shown their activity. Attention to the explanations of the model teacher is still lacking, unfocused, collaboration within the group has not been seen, each group member is busy looking for his own answers from the material, not helping each other in solving problems. The results that show the results of student achievement for all indicators of communication skills in cycle 1 can be seen in Figure 1.

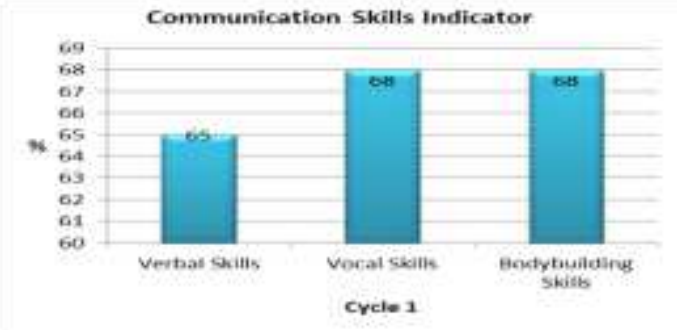

Fig. 1. The achievement of indicators of communication skills in cycle 1 In Figure 1 it can be seen that an increase in the percentage achieved or obtained by students for all indicators of communication skills in the cycle. In cycle 1 shows that most of the students have not shown adequate results for all indicators of communication skills. In the aspect of verbal skills (including ideas and concepts through language) only a percentage value of $65 \%$ is obtained. This shows the fact that students still tend to use words in their local language in expressing opinions, answering questions. In addition, the substance of the contents of the idea has not been coherent, not in accordance with what the questioner wants, the meaning expressed in bringing up the idea is still ambiguous, and the choice of many words is incorrect. While the percentage obtained in indicators of vocal skills (including articulation, intonation, tempo, accentation and volume) is $68 \%$. Researchers find that students are still inclined to have a tone or intonation that is not appropriate in the delivery (talk). Furthermore, the tempo is too fast and the volume is too small, the intonation is not stable, the placement of accents is still not right, there are still many who use voices such as "mm", "e", "o", "um", when asking and responding friend's question. Students have no courage, are still anxious and nervous about expressing their opinions in the learning process. This weakness is also still commonly found in the body skills indicator which only gets a percentage of $68 \%$. Visible students are still showing facial expressions of anxiety, depression, fear, doubt. This explains that students still have facial expressions, eye contact, gestures are still inadequate.

Some other problems were also found, namely only a few students who had demonstrated good communication skills gave ideas coherently and logically. This can be seen at the time of question and answer (discussion) activities provided by the model teacher. The rest of the communication activities are not many students who dare to talk and express opinions, ask questions or intuit.

The learning conditions in cycle 1 were made possible because the model teacher was not yet familiar with students, did not understand the students' emotional conditions, also the model teachers in the learning process were still lacking and had not carried out the collaborative learning process ideally as planned in the lesson plan. Based on the results of teacher observation and student observation at the observation stage, communication skills of students who have not achieved the expected results, this is natural, because at this first meeting new students are familiar with collaborative learning, not yet accustomed to the learning conditions that want communication skills.

Furthermore, the results of reflection on the learning process seen from students is that most of the students have not demonstrated adequate communication skills. Based on the results of reflection in cycle 1 that the lesson plan (RPP) must be improved by emphasizing the emergence of student communication skills, the teacher needs to improve the implementation of learning in accordance with the standard process. Improving the process of implementing learning, will be able to increase student enthusiasm to talk, respond, ask questions in the learning process and ultimately will improve students' communication skills. The result of reflection is that the teacher must be more open, the learning plan at the core stage must involve students, be centered on students, explore the potential of students, motivate them to express their opinions, responses and ask questions in the learning process to achieve learning indicators and bring up their communication skills.

\subsubsection{Cycle 2}

In the second cycle of learning the results show that students already know the model teacher well, this can be seen from the behavior of students who have expressed serious interest, enjoy, they have no doubt, are not nervous and have shown their activeness. Attention to the teacher's explanation of the model has been focused, there has been collaboration in groups, group members together looking for answers to the assignments given by the teacher, helping each other in solving problems. The achievement data for all indicators of communication skills in the second cycle of research as 
follows.

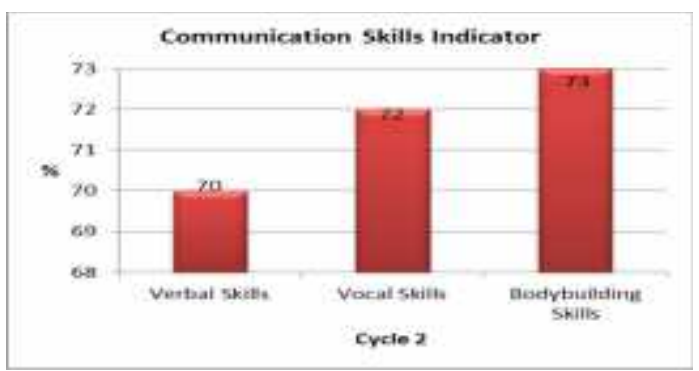

Fig. 2. Achievement of communication skills indicators in cycle II Figure 2 explains that in cycle II the achievements obtained by students for all indicators of communication skills are on average 70 ie 70 (verbal skills), 72 (vocal skills), and 73 (body skills). This shows that there has been a change (increase) in achievement from the previous cycle, in which most students have shown their active communication skills. Students are more enthusiastic to answer and respond to questions from friends and teachers. Besides that, it was apparent that most students had listened to their friends' opinions, seriously, and were attentive to the responses expressed by their friends. Not only that students are also more enthusiastic about giving bright ideas when the question and answer opportunity and discussion given by the model teacher. Students already have the courage to ask questions and are able to answer questions from the teacher or other students. In addition, students can already answer according to questions, the choice of words is appropriate and appropriate, the substance of the contents of the ideas that have been found have started coherent. In cycle II communication skills on the Verbal Skills indicator of students are more visible and there is an increase. This indicator also shows a significant change. It can be seen that the tempo of speech of students has begun to adjust to the situation, not too fast and the volume is not too small or not too big. In addition, changes also appear in stable intonation, accentation placement has begun to show conformity and accuracy, and students do not use fill voices such as "mm", "e", "o", "um". The existence of some positive changes (improvements) can not be separated from the reflection at each meeting, where students are always reminded and taught by the model teacher. Furthermore, for indicators of body skills, the second cycle has shown changes. Facial expressions and eye contact of students, happy, not afraid because students have begun to adjust to the learning situations and conditions.

Looking at the learning situations and conditions in cycle II it can be concluded that there was a significant improvement. Some of these increased changes are caused by several factors including: 1). Students do not have the burden to talk in front of the class, this can be seen from the students' happy, happy expressions. 2). The model teacher is familiar with students, already understands students' emotional states. 3) The model teacher in the learning process has carried out the learning process as planned in the lesson plan. Based on the results of teacher observation and student observation at the observation stage, communication skills of students who have achieved the expected results, almost all students have the courage to speak in front of the class, have dared to respond to the results of friends' questions, most have shown enthusiasm, strong motivation to respond to a friend's question.

\subsection{Discussion}

The results of this class action research are that there is an increase in communication skills in learning Indonesian with Collaborative Learning, both verbal skills, vocal skills, and body skills. This can be shown by the value of communication skills in cycle 1 by $67 \%$, increasing in cycle 2 by $72 \%$. This improvement proves that the collaborative learning method can motivate students to communicate well. This is following the opinion of Widodo (2013), collaborative learning as a learning strategy with several students as members of a learning group who work actively to achieve the goals set in an activity with a certain structure so that a meaningful learning process occurs.

Communication skills are the demands and logical consequences of the learning process. The ability to communicate is also an ability in the art of rhetoric in argumentation (Noermanzah, et. Al., 2019: 1794). When able to communicate, students will master the $4 \mathrm{C}$ competencies in the other 21st century namely critical thinking, creative, and collaborating (Noermanzah \& Friantary, 2019:6631). Besides communication skills are considered as an essential or important skill in a soft skill (Soft Skill) which can be a competency as a pointer or determinant of one's success to other language competencies. This is relevant to Ridha (2018: 19) \& Okoro et al., (2017) statement, which revealed that communication skills were identified as interpersonal competencies and communication effectiveness that was essential for success. Facts on the ground show that the learning process without active communication rarely happens. The problem only lies in the level and quality of student communication.

In the implementation of learning, when viewed communication skills show a process in accordance with the opinion of Fujishin (2009) that in communication there are three processes, namely: 1) a process, communication is a process/something that continues and changes; 2) create messages, the ability of individuals to create messages from the dimensions of verbal and non verbal communication; and 3) exchanging messages, after choosing nonverbal words, sentences, and cues to form thoughts or feelings that individuals want to communicate, individuals send messages to recipients, who process messages and provide feedback in the form of feedback. In the first cycle, the levels or weights of students' communication skills are inadequate and still low. Many factors influence it, among others, the stimulus delivered by the model teacher has not communicated the information desired by students so that many students are still confused about what will be done, what will be done in the learning. Attention and motivation, as well as student responses, are also the main prerequisites in the learning process. The model teacher is not aware of this, because his attention is only on how he conveys the material and students do what they want so that students' attention and motivation and responses are ignored. Also, the model teacher has not done an ideal reinforcement such as approval of student opinions, recognition of student responses to the matter of reinforcement is a source of learning 
reinforcement to satisfy student needs.

In the second cycle, it shows changes in the activeness and communication skills of students both verbal, vocal and body skills. The model teacher and students have realized their respective roles. Viewed from the teacher's point of view, the model teacher has tried his best to encourage, foster a passion for learning and active student participation, the model lecturer does not dominate learning activities, and allows students to learn according to their ways and circumstances, using various teaching methods with a multimedia approach.

Body skills (gesture) from cycle one and cycle two increase beyond vocal skills and verbal skills. This is highly expected because by increasing these skills strengthen and interpret the message conveyed in the learning process. This is reinforced by the opinion of Nofrion (2018), who said that gesture as a member of the body movements will strengthen the message, help the message arrive which is difficult to understand with spoken language and increase attention. The gesture will add flavor and strengthen the meaning of spoken language.

In terms of the learning program, the interactional goals given by the teacher as well as the concepts and content of learning are by the needs and abilities of students, the learning material already contains information, concepts, principles, and skills. Seen from the students, responding to what the model teacher has done is the desire and courage to communicate by displaying their interests and problems, participating in learning activities, displaying various learning efforts in living and completing learning activities. The success in communicating students is greatly influenced by communication between individuals (Ridha, 2018: 19). For that reason, communication skills are comprehensive which includes verbal and non-verbal aspects that influence each other between one individual and another to create the same understanding of the message being communicated.

\section{CONCLUSION}

From the results of research and discussion, it can be concluded that there is an increase in communication skills in learning Indonesian with Collaborative Learning, both verbal skills, vocal skills, and body skills. This can be shown by the value of communication skills in cycle 1 by $67 \%$, increasing in cycle 2 by $72 \%$. In cycle 1 aspects of verbal skills (including ideas and concepts through language) only obtained a percentage value of $65 \%$; indicators of vocal skills (including articulation, intonation, tempo, accentuation, and volume) are $68 \%$. While the body skills that only get a percentage of $68 \%$. In cycle 2 there was an increase, aspects of verbal skills (including ideas and concepts through language) obtained a percentage value of $70 \%$; indicators of vocal skills (including articulation, intonation, tempo, accentuation and volume) are $72 \%$. While the body skills obtained $73 \%$ percentage. From the results of this study, it is hoped that Indonesian language teachers can use the Collaborative Learning method as one method in improving student communication learning.

\section{REFERENCES}

[1] Chaer, A., \& Agustina, L. (2004). Sosiolinguistik: Perkenalan Awal. Jakarta: Penerbit PT Rineka Cipta.

[2] Dharmayanti, P. A. (2013). Teknik Role Playing dalam Meningkatkan Keterampilan Komunikasi Interpersonal Siswa SMK. Jurnal Pendidikan dan Pengajaran, 46(3).

[3] Fujishin, R. (2009). Creating Communication: Exploring and Expanding Your Fundamental Communication Skills. (2nd Edition). America: Rowman \& Littlefield Publishers, Inc.

[4] Hardjana, A. M. (2003). Komunikasi Interpersonal dan Intrapersonal. Yogyakarta: Kanisius.

[5] Hill, S. \& Tim. (1996). The Collaborative Classroom, a Guide to Cooperative Learning. Armadale: Eleanor Curtain Publishing. Armadale: Eleanor Curtain Publishing.

[6] Karto, Suhartono, Susetyo, Noermanzah, Maisarah, I. (2019). The Differences Ability in Writing Descriptive Texts by Using Chain Writing and Conventional Methods. International Journal of Scientific and Technology Research, 8(10).

[7] Maulana, H., \& Gumelar, G. (2013). Psikologi Komunikasi dan Persuasi. Jakarta: Akademia Pratama.

[8] Nelson, R. \& Jones. (2012). Pengantar Keterampilan Konseling. Introduction to Counseling Skills. Yogyakarta: Pustaka Pelajar.

[9] Noermanzah \& Friantary, H. (2019). Development of Competency-Based Poetry Learning Materials for Class X High Schools. International Journal of Recent Technology and Engineering, Volume-8, Issue-4, November 2019.

[10] Noermanzah, Wardhana, D. E. C., Friantary, H., Arsyad, S. (2019). Joko Widodo's Rhetorical Structure in the Presidential Speeches for Addressing Educational Problems. International Journal of Scientific and Technology Research, $8(10)$.

[11] Nofrion, N. (2018). Pentingnya Keterampilan Komunikasi di Era Revolusi Industri 4.0. doi:10.31227/osf.io/krw28.

[12] Okoro, E., Chwashington, M., \& Thomas, O. (2017). The Impact of Interpersonal Communication Skills on Organizational Effectiveness and Social Self-Efficacy: A Synthesis. International Journal of Language and Linguistics, 4, 28-32.

[13] Ridha, A. A. (2018). Efektivitas Pelatihan Komunikasi untuk Meningkatkan Keterampilan Komunikasi Siswa Kejuruan Jurusan Akomodasi Perhotelan. Analitika, 10(1), 19. doi:10.31289/analitika.v10i1.1504

[14] Suryani, N. (2009). Implementasi Model Pembelajaran Kolaboratif untuk Meningkatkan Ketrampilan Sosial Siswa. Majalah Ilmiah Pembelajaran, 8(2).

[15] Wicaksono, G. (2013). Penerapan Teknik Bermain Peran dalam Bimbingan Kelompok untuk Meningkatkan Kemampuan Komunikasi Interpersonal Siswa Kelas X Multimedia SMK IKIPSurabaya. Jurnal BK UNESA, 1(1).

[16] Widodo, U. (2013). Penerapan Metode Pembelajaran Kolaboratif untuk Meningkatkan Prestasi Belajar Siswa Kelas X pada Mata Pelajaran Membaca Gambar Sketsa di SMK Negeri 2 Klaten. Skripsi. Yogyakarta: Universitas Negeri Yogyakarta. Diakses dari: http://library.uny.ac.id/freecontents/index.php/pub/detail/penerapan-model-pembelajarankolaboratif-untuk-meningkatkan-kualitas-hasil-belajar-ipa-siswa-smk-2klaten-urip-widodo-48624. html.

[17] Zuhara, E. (2015). Efektivitas Teknik Sosiodrama untuk Meningkatkan Komunikasi Interpersonal Siswa (Penelitian Kuasi Eksperimen Kelas X di SMA Kartika Siliwangi 2 Bandung Tahun Ajaran 2013/2014). Jurnal Edukasi: Jurnal Bimbingan Konseling, 1(1), 80-89. 